\title{
Article \\ Oil Recovery from Dry Grind Ethanol Plant Coproducts Using Ethanol
}

\author{
Md. Sanaul Huda and Nurun Nahar*
}

check for

updates

Citation: Huda, M.S.; Nahar, N. Oil Recovery from Dry Grind Ethanol Plant Coproducts Using Ethanol. Processes 2021, 9, 2282. https:// doi.org/10.3390/pr9122282

Academic Editor: Farid B. Cortés

Received: 9 November 2021

Accepted: 10 December 2021

Published: 20 December 2021

Publisher's Note: MDPI stays neutral with regard to jurisdictional claims in published maps and institutional affiliations.

Copyright: (C) 2021 by the authors Licensee MDPI, Basel, Switzerland. This article is an open access article distributed under the terms and conditions of the Creative Commons Attribution (CC BY) license (https:/ / creativecommons.org/licenses/by/ $4.0 /)$.
Department of Agricultural and Bio-Systems Engineering, North Dakota State University, Fargo, ND 58102, USA; mdsanaul.huda@ndsu.edu

* Correspondence: nurun.nahar@ndsu.edu; Tel.: +1-701-231-7140

\begin{abstract}
Corn ethanol bio-refineries are seeking economic processing strategies for recovering oil from their coproducts. The addition of ethanol can be an efficient method to recover the oil from the coproducts as the industry has available ethanol. This study considered the effects of ethanol on oil recovery from distillers' dried grains with solubles (DDGS) and oil partitioning from whole stillage (WS) on a laboratory scale. Ethanol was added with original and heavier fraction DDGS in different temperatures (room temperature $\sim 20^{\circ} \mathrm{C}, 30^{\circ} \mathrm{C}, 40^{\circ} \mathrm{C}$, and $50{ }^{\circ} \mathrm{C}$ ) and solids loadings $(20 \%, 30 \%$, and $40 \%$ ), and their effects on oil recovery were evaluated. The whole stillage was incubated with ethanol at room temperature $\left(20^{\circ} \mathrm{C}\right)$ and $50^{\circ} \mathrm{C}$ separately to analyze WS's oil distribution in the liquid and solid phases. The amount of recovered oil from the original and heavier fractions of DDGS varies from $25-45 \%$ and $45-70 \%$, respectively, with an increment of temperature. Increasing solids loadings up to $30 \%$ had no effect on oil recovery from either DDGS sample. Ethanol treatment in WS resulted in $8-10 \%$ higher wet yield of liquid fraction and $17-20 \%$ of oil increase in liquid fraction than the control treatment. It is also notable that temperature positively impacted oil partitioning from WS. The results showed that ethanol could improve oil recovery from DDGS and oil partition in WS by varying different process conditions. This outcome is beneficial to ethanol plants to increase corn oil yield using their existing setup and in-situ product.
\end{abstract}

Keywords: DDGS; whole stillage; oil recovery; ethanol; solids loading; temperature

\section{Introduction}

The recent development of fuel ethanol generation has resulted in the increased accessibility of ethanol coproducts. Recovery of coproducts accounts for almost $31 \%$ of the total revenue for some ethanol plants, and is considered one of the key factors for the economic sustainability of the ethanol industry [1]. As the industry grows, there will be an increased need to find other uses for ethanol coproducts. After the separation of ethanol, the remaining slurry (whole stillage) is divided between the liquid fraction (thin stillage), and the solid fraction is dried to produce dried distiller grain with soluble (DDGS). The value of DDGS is underrated in terms of its composition and is usually utilized in animal feed formulation [2]. DDGS contains 8-10\% oil (based on dry weight), which is higher than the amount required for animal feed [3]. As the increase of oil in DDGS negatively impacts feed quality by reducing the milk production in cattle and bacon-texture in swine, it is undesirable for the dairy and meat industries [4]. As oil is a higher value product than animal feed, there is much interest for the biorefinery industry in recovering oil from ethanol coproducts.

Oil recovery from post-fermentation (at the back end) is considered more feasible due to the absence of the germ separation stage after initial grinding [5]. One possible strategy to improve oil recovery from the dry-grind process is to shift more oil distribution to the thin stillage (liquid fraction). The oil separation from the liquid phase is much easier, and it can be achieved by using existing centrifuges or decanters. Noureddini et al. [6] reported 
that an organic solvent could be used for a low oil content product such as whole stillage containing around $2-3 \%$ oil (17-18\% on a dry basis) for better oil recovery. Consequently, it is assumed that adding ethanol with whole stillage could enhance oil partition in the thin stillage. Different methods to break (e.g., extrusion, grinding, flaking) corn kernels before fermentation [7] and enzymatic treatments during or after fermentation $[4,8,9]$ were used to achieve increased oil partitioning in thin stillage. Consequently, the research into the better recovery of aqueous corn oil from DDGS and WS using ethanol appears to be reasonable.

Hexane is the most commonly used solvent and is typically favored by the oil refining industry [10]. However, the use of hexane has few disadvantages as this substance is not only very toxic and flammable but also a dangerous air pollutant [11]. Therefore, many laboratory-scale eco-friendly processes have been studied to recover corn oil, including aqueous enzymatic processes [12-15] and supercritical fluid extraction [16,17]. The aqueous enzymatic approach, however, has economic concerns that have limited its large-scale industrialization. In addition, the usual high dosage of enzymes causes high production costs, which are not economically feasible.

Recovery of aqueous corn oil from DDGS and WS using ethanol may be promising as ethanol is non-toxic, and readily available to the bio-refinery industry. In the internal reaction mechanism, the diluted aqueous ethanol solution might adjust the local emulsion micro-environment, causing the structure of organized molecular water around emulsion drops to collapse [18]. However, the recovered oil was found in the form of a cream emulsion [19]. A stable emulsion must be broken; otherwise, the oil yield cannot reach the maximum. High concentrations of ethanol have been commonly known as a demulsifier [20]. Besides, ethanol is readily available to the bio-refinery industry. Therefore, no additional cost is required for solvent storage and transportation, making it beneficial for the industry to choose this option for a profit.

This study investigated the potential to use ethanol in varying conditions to increase oil recovery from DDGS and oil partition from whole stillage to thin stillage (liquid fraction). The first objective was to analyze the effect of a heavier fraction of DDGS on oil recovery using ethanol. The second objective aimed to determine the effect of ethanol (190 proof, 95\% by volume) addition with whole stillage on oil partitioning. Fractionated DDGS and whole stillage were tested with ethanol to recover oil. Different operating conditions (e.g., type and degree of hydration of solvent and temperature) were examined to achieve higher oil yields than original DDGS and more oil partition in the liquid fraction of whole stillage.

\section{Materials and Methods}

\subsection{Raw Materials and Chemicals}

The DDGS sample used in this experiment was collected from the Blue Flint Ethanol Plant (Underwood, ND, USA) and stored at $4-6{ }^{\circ} \mathrm{C}$ until used. The same batch of DDGS was used throughout the study to reduce the variability of the DDGS composition. The collected DDGS sample was fractionated using a standard sieve shaker (Ro-Tap W. S. Tyler, Mentor, OH, USA) and a laboratory aspirator (Model 6DT4-1, KICE Metal Products Co., Inc., Wichita, KS, USA). Methods of fractionation by sieving and aspiration were followed as described in Huda et al. [21]. Representative sample of original DDGS (around $1 \mathrm{~kg}$ ) was sieved through selected US standard sieves of Nos. 10, 20, 40, 60 and a pan without additional processing and moisture adjustment. The yield (\%) retained on each sieve size was calculated. The sieved and original DDGS sample was fed by gravity into an open feed hopper of the laboratory aspirator unit. The air baffle of the aspirator was set at a 75-degree angle so that pressure at the inlet of the cyclone was $6.35 \mathrm{~mm}$ (0.25-inch) water column. The stated air pressure was selected from a preliminary experiment, mainly focusing on the fiber and oil content of different fractions with different air pressure to have a reasonable yield of all fractions. The whole stillage and ethanol were collected from a local biorefinery plant (Hankinson Renewable Energy, LLC, Hankinson, ND, USA). The whole stillage was stored in the freezer at a temperature of $-18{ }^{\circ} \mathrm{C}$ to $-20{ }^{\circ} \mathrm{C}$. The sample was thawed to 
room temperature and mixed vigorously to ensure homogeneity of the sample before the experiment.

\subsection{Proximate Analyses}

The primary sample of DDGS is termed as "original," in contrast to sieved/aspirated fractions. The original DDGS, sieved-aspirated DDGS, and the whole stillage samples were measured for moisture, protein, and oil content. The moisture content was determined by drying samples in an oven at $105^{\circ} \mathrm{C}$ for $3 \mathrm{~h}$ [22]. The combustion method was followed for determining protein contents using a factor of 6.25 to convert percent nitrogen to percent protein [22]. An accelerated solvent extractor (ASE200 solvent extractor, Dionex, Sunnyvale, CA, USA) was used to measure the oil content according to the official methods [23]. In this method, $6 \mathrm{~g}$ of dried samples were mixed with approximately $2 \mathrm{~g}$ of diatomaceous earth and ground in a small grinder. The ground sample was loaded in 11-mL extraction cells. A cellulose filter was placed at the outlet end of the extraction cell before loading the sample. The extraction conditions in the cells were as follows: a pressure of $6895 \mathrm{kPa}$ (1000 psi), the temperature of $100{ }^{\circ} \mathrm{C}$, heat time of $5 \mathrm{~min}$, start time of $10 \mathrm{~min}$, three static cycles, $100 \%$ flush volume, and purge time of $60 \mathrm{~s}$. Upon completion of the extraction, preweighed collection vials were placed in an evaporator with a water bath to evaporate the solvent. Then the residue was weighed to determine the percent of the oil in the original sample. This oil quantification was used as the base to calculate oil recovery. The moisture content was used to convert concentrations of other components (crude protein and oil content) into a dry matter basis.

\subsection{Oil Recovery from DDGS Using Ethanol}

Oil was recovered from DDGS using aqueous ethanol as a solvent, according to $\mathrm{Ni}$ et al. [24]. Batch experiments were carried out in 125-mL Erlenmeyer flasks, kept in a constant temperature water bath (MaxQ 7000, Thermo Scientific, Dubuque, Iowa). Each treatment was carried out with $10 \mathrm{~g}$ of dry DDGS sample. Ethanol ( $95 \%$ by volume) was mixed with the DDGS fractions according to different solid loadings of $20 \%, 30 \%$, and $40 \%$, respectively. The experiment was conducted for $2 \mathrm{~h}$ at $130 \mathrm{rpm}$ with different temperatures (Room temperature $\sim 20^{\circ} \mathrm{C}, 30^{\circ} \mathrm{C}, 40^{\circ} \mathrm{C}$, and $50{ }^{\circ} \mathrm{C}$ ). The mixtures were added into Erlenmeyer flasks, and both the time and shaker were started after it reached its desired temperature. The Erlenmeyer flasks were closed with aluminum foil paper to prevent any mass loss due to evaporation. After incubation, all mixtures were poured into 100-mL centrifuge tubes and centrifuged (Allegra X-15R Benchtop Centrifuge, Beckman Coulter, Fullerton, CA, USA, fitted with a SX4750 swinging bucket rotor, $20.78 \mathrm{~cm}$ radius at $4750 \mathrm{rpm}, 5250 \times \mathrm{g}$ ) at $25^{\circ} \mathrm{C}$ with $4500 \mathrm{rpm}$ for $20 \mathrm{~min}$. The centrifuged mixture was transferred to pre-weighed round-bottom vials using a Buchner funnel and 8- $\mu \mathrm{m}$ filter paper (Whatman No. 2) to remove the solid residue. Free oil was measured by weighing the solvent (ethanol) from the vials after evaporation. The solvent was removed by an evaporation system equipped with a water bath (Microprocessor Controlled 280 Series, Thermo Electron Corporation) at $60^{\circ} \mathrm{C}$. Any residual solvent remaining in the mixture was removed using a vacuum oven. The weight of the oil was then determined gravimetrically. Oil recovery was calculated based on the oil content determined by the accelerated solvent extraction method for the specific fractions of DDGS used. The yield of oil was expressed using Equation (1):

$$
\text { Yield }(\%)=\frac{\text { free oil weight }(\mathrm{g})}{\text { total oil in DDGS }(\mathrm{g} / 10 \mathrm{~g} \text { DDGS })} \times 100
$$

\subsection{Oil Partitioning Experiment}

A specified amount $(87.50 \mathrm{~g})$ of whole stillage was transferred into the Erlenmeyer flask and kept in a constant temperature water bath (MaxQ 7000, Thermo Scientific, Dubuque, IA, USA). Before placing the whole stillage sample, vigorous mixing was performed in 
the storage bottle to ensure a homogenous sample. Each treatment was carried out for $2 \mathrm{~h}$ at $130 \mathrm{rpm}$ with a specified temperature. Two temperatures were selected: room temperature $\left(\sim 20^{\circ} \mathrm{C}\right)$ and $50{ }^{\circ} \mathrm{C}$. Ethanol was added to the flask according to the selected amount of solids to dry whole stillage solids content. Another treatment was introduced by mixing distilled water with the whole stillage to investigate the effect of various solids content on oil partitioning from the whole stillage. The amount of distilled water mixed was determined to have the same solids content of whole stillage in ethanol treatment. The control treatment had no ethanol and water but was treated in different temperature conditions. The Erlenmeyer flasks were closed with aluminum foil paper to prevent any mass loss due to evaporation. After incubation, the liquid and solid portions were obtained using centrifugation (Allegra X-15R Benchtop Centrifuge, Beckman Coulter, Fullerton, CA, fitted with a SX4750 swinging bucket rotor, $20.78 \mathrm{~cm}$ radius at $4750 \mathrm{rpm}, 5250 \times \mathrm{g}$ ) of $3750 \mathrm{rpm}$ for $20 \mathrm{~min}$ in a 100-mL centrifuge tube.

\subsection{Sample and Yields Analysis from Whole Stillage}

Representative solid samples from all treatments were dried at $65{ }^{\circ} \mathrm{C}$ and analyzed in duplicate for oil recovery using ASE as described in Section 2.2. The oil partition in the liquid was calculated from the difference between the oil in the whole stillage and the solid portion. The three fractions (whole stillage, solid and liquid portion after centrifuge) were considered to follow these relationships of mass balance [4]:

$$
\begin{gathered}
\mathrm{Y}_{\mathrm{sf}}+\mathrm{Y}_{\mathrm{lf}}=100 \\
\mathrm{~S}_{\mathrm{sf}}+\mathrm{S}_{\mathrm{lf}}=\mathrm{S}_{\mathrm{ws}} \\
\mathrm{Y}_{\mathrm{sf}} \times \% \text { solid }_{\mathrm{sf}}+\mathrm{Y}_{\mathrm{sf}} \times \% \text { solid }_{\mathrm{sf}}=100 \times \% \text { solid }_{\mathrm{ws}}
\end{gathered}
$$

where, $\mathrm{Y}=\%$ yield on a wet-weight basis, $\mathrm{S}=$ solid on a dry basis, and the subscripts sf, lf, and ws denote the solid fraction, liquid fraction, and whole stillage, respectively. The term $\%$ solid was the solids content in the corresponding sample.

The wet and dry-matter yields and the solids content of liquid and solid portion were calculated by measuring the wet and dry matter weights corresponding to the whole stillage using Equations (5)-(7):

Wet yield of solid fraction $(\%)=\frac{\mathrm{g} \text { of solid fraction, as-is }}{\mathrm{g} \text { of whole stillage, as-is, before centrifugation }} \times 100$

Percent solid in solid fraction $(\%)=\frac{\mathrm{g} \text { of dry matters in solid fraction, as-is }}{\mathrm{g} \text { of dry matters whole stillage, before centrifugation }} \times 100$

Oil partition in liquid fraction $(\%)=\frac{1-\mathrm{g} \text { of oil in solid fraction, as-is }}{\mathrm{g} \text { of oil in whole stillage, as-is, before centrifugation }} \times 100$

\subsection{Statistical Analysis}

All statistical tests were performed using the SAS software version 9.1 (SAS Institute, Cary, NC, USA). Analysis of variance (ANOVA) using a 95\% confidence level was conducted to evaluate significant differences among treatments. The least significant differences (LSD) was also calculated to determine the significant difference between means. A value of $p<0.05$ based on the ANOVA was considered to indicate statistically significant differences. Each experiment was conducted individually with a completely randomized treatment design. All treatments were carried out in triplicate, and results are shown as the means of triplicates \pm standard deviation (SD).

\section{Results and Discussion}

\subsection{Effects of Ethanol on Oil Recovery from DDGS}

Aqueous ethanol (190 proof) was used as a solvent and chemical demulsifier to recover oil. This study considered two critical parameters; the process temperature and the solids 
loading of different fractions of DDGS relative to ethanol. Selected process temperatures were room temperature $\left(\mathrm{RT} \sim 20^{\circ} \mathrm{C}\right), 30^{\circ} \mathrm{C}, 40{ }^{\circ} \mathrm{C}$, and $50{ }^{\circ} \mathrm{C}$, while the different solids loadings were fixed at $20 \%, 30 \%$, and $40 \%$.

\subsubsection{Composition of Original and Fractionated DDGS}

The yields sieving and aspiration of different DDGS fractions were previously reported in Huda et al. [21]. The highest yield was found during sieving with particle size between $0.42-0.84 \mathrm{~mm}$ sieve (DDGS retained on \# 20 sieve) and chosen for aspiration to separate heavy fraction. This heavy fraction of DDGS (\# 20 sieved and aspirated) was selected for oil recovery based on the yield and composition of the different fractions. The composition of the original DDGS and heavy fraction DDGS (\#20 sieved and aspirated) used in the experiment are shown in Table 1.

Table 1. Oil, moisture, and crude protein content of original and heavy fraction DDGS.

\begin{tabular}{ccc}
\hline Composition (\%) & Original DDGS * & Heavy Fraction DDGS (\# 20 Sieved and Aspirated) ${ }^{*}$ \\
\hline Oil & $9.8 \pm 0.05$ & $12.20 \pm 0.08$ \\
Moisture & $11.5 \pm 0.66$ & $9.50 \pm 0.73$ \\
Crude protein & $32.6 \pm 0.29$ & $32.10 \pm 0.47$ \\
\hline
\end{tabular}

${ }^{*}$ Mean of triple measurements \pm standard deviation.

The oil content in the heavy fraction of DDGS (\# 20 sieved and aspirated) was $24 \%$ higher than the original DDGS due to the fractionation process (Table 1). The moisture content of the original DDGS and heavy fraction DDGS (\# 20 sieved and aspirated) used in the experiment were determined to be $11.5 \%$ and $9.5 \%$, respectively. The low moisture level in fractionated DDGS relative to the original DDGS is due to the aspiration, which is considered a partial drying process. There was no significant change between the crude protein content of the fractionated sample compared to that of the original DDGS.

\subsubsection{Effects of Temperature}

The change in the amount of oil recovered with the variation of process parameters in original and heavy fraction (\# 20 sieved and aspirated) DDGS are presented in Figures 1 and 2, respectively. With the increase in temperature from room temperature $\left(\sim 20^{\circ} \mathrm{C}\right)$ to $50{ }^{\circ} \mathrm{C}$ (regardless of the solids loadings), a significantly increased amount of oil was recovered from both types of DDGS samples used. From Figures 1 and 2, it is apparent that the highest amount of oil was recovered at $50^{\circ} \mathrm{C}$. However, the increment of the oil recovery with the increase in temperature differs for the type of DDGS fraction. For example, the amount of oil recovered increment ranges between $45-70 \%$ in heavy fraction (\# 20 sieved and aspirated) DDGS. On the contrary, a lower increment (25-45\%) was noted when the original DDGS was used.

Johnson [25] showed that oil's solubility in alcohol depends on temperature, and with temperature increase, oil solubility increases, which justifies findings of getting a high oil yield at a high temperature. Moreover, heating is also considered a practical means of demulsifying [26]. Singh and Cheryan [27] also found a reasonable amount $(0.66 \mathrm{~g}$ oil $/ 10 \mathrm{~g}$ of DDGS) of oil from DDGS at $50{ }^{\circ} \mathrm{C}$, when anhydrous ethanol was used as a solvent. Temperature is, however, a very critical input for the biorefinery industry. An optimized temperature where a significant amount of oil is recovered provides the biorefinery with more oil output and possible energy savings. 


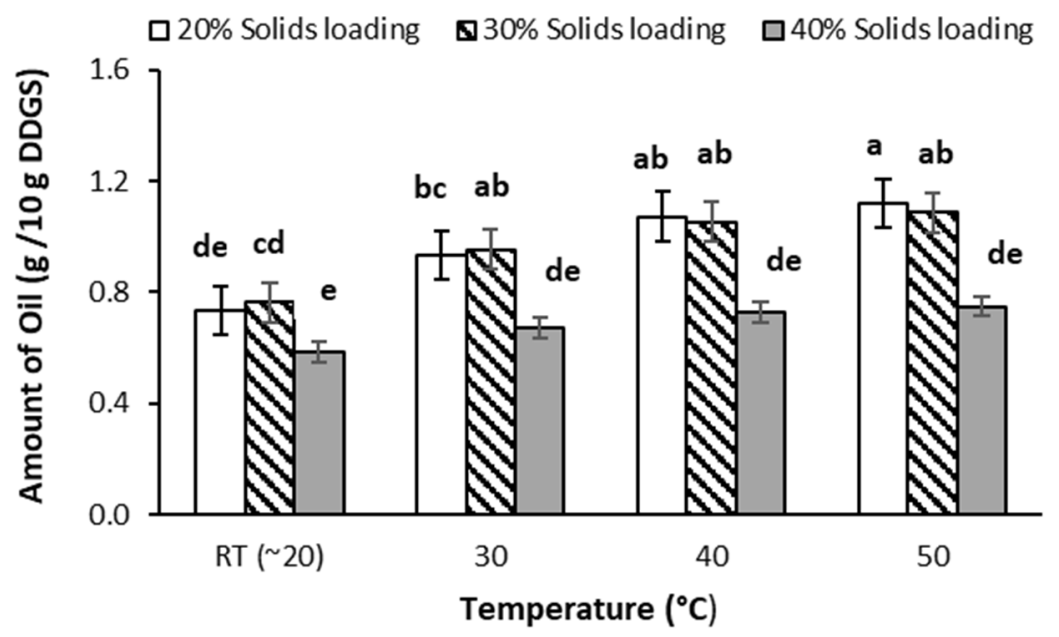

Figure 1. Effects of temperature and solids loadings on the amount of oil recovered from the original DDGS. Letters a-e refer to the significant difference from each other.

\section{$\square 20 \%$ Solids loading $\quad \mathbf{\Delta 3 0 \%}$ Solids loading $\quad \square 40 \%$ Solids loading}

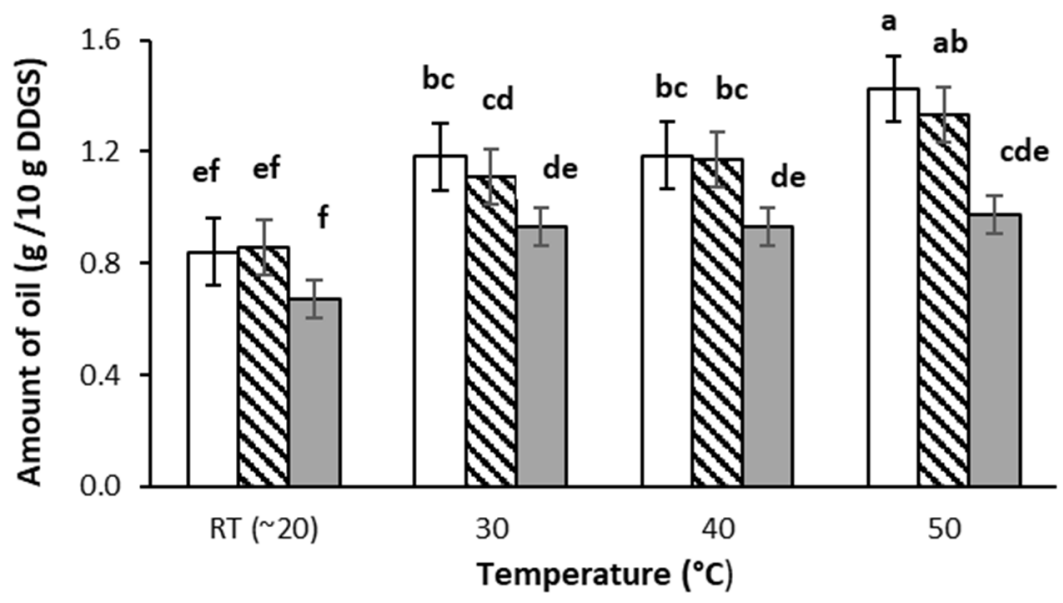

Figure 2. Effects of temperature and solids loadings on the amount of oil recovered from heavy fraction DDGS (\# 20 sieved and aspirated). Letters a-f refer to the significant difference from each other.

\subsubsection{Effects of Solids Loading}

Different solids loadings were evaluated to determine their impact on oil yields from different fractions of DDGS, as shown in Figures 1 and 2. When the solids loading increased from $20 \%$ to $40 \%$, the amount of oil recovered from the DDGS samples decreased considerably at all the temperature conditions $\left(\mathrm{RT} \sim 20^{\circ} \mathrm{C}, 30^{\circ} \mathrm{C}, 40^{\circ} \mathrm{C}\right.$, and $50{ }^{\circ} \mathrm{C}$ ). It is seen from Figures 1 and 2 that the amount of oil recovered from the original and heavy fraction (\# 20 sieved and aspirated) DDGS was significantly different at $20 \%$ and $40 \%$ solids loadings, at a higher temperature than room temperature $\left(\sim 20^{\circ} \mathrm{C}\right)$. Unlike the impact of temperature, the amount of recovered oil did not vary with the type of DDGS fraction. For both types of DDGS samples, the decrease in oil ranged from $20-35 \%$ (regardless of the temperature).

The addition of ethanol at various solids loadings increases the recovery of oil from DDGS. Kadioglu et al. [28] stated that when ethanol applied to the oil extraction system, it affects the interfacial tension (IFT). The IFT of ethanol and water is $22.39 \mathrm{mN} / \mathrm{m}$ and $72.75 \mathrm{mN} / \mathrm{m}$ at $20^{\circ} \mathrm{C}$ [28]. Consequently, the IFT and the polarity between water and alcohol will decrease, when the ethanol concentration increases in the solution. The lower IFT value of ethanol than water will facilitate pathways for the release of oil and increase the oil yield [29], which could be why higher oil yields have lower solids loadings (20-30\%). 
3.1.4. Effects of Oil Recovery from Heavy Fraction (\#20-Sieved-Aspirated) of DDGS at Different Temperatures and Solids Loadings

Figure 3 displayed the influence of temperature on oil recovery from heavy fraction (\# 20 sieved and aspirated) DDGS at 20\%,30\%, and 40\% solids loadings. Overall, the oil recovery increased with the increasing temperature (Figure 3). For example, more than $90 \%$ of the oil was recovered at $20 \%$ and $30 \%$ solids loadings when treated at temperatures $30{ }^{\circ} \mathrm{C}$ and $40{ }^{\circ} \mathrm{C}$, although oil recovery did not change significantly as the temperature increased over $30^{\circ} \mathrm{C}$. Notably, the oil recovery reached nearly $100 \%$ when the temperature reached $40{ }^{\circ} \mathrm{C}$ for $20 \%$ and $30 \%$ solids loading. However, increasing temperature up to $50^{\circ} \mathrm{C}$ was not significantly different than $30^{\circ} \mathrm{C}$ or $40^{\circ} \mathrm{C}$ for $40 \%$ solids loading (data not shown).

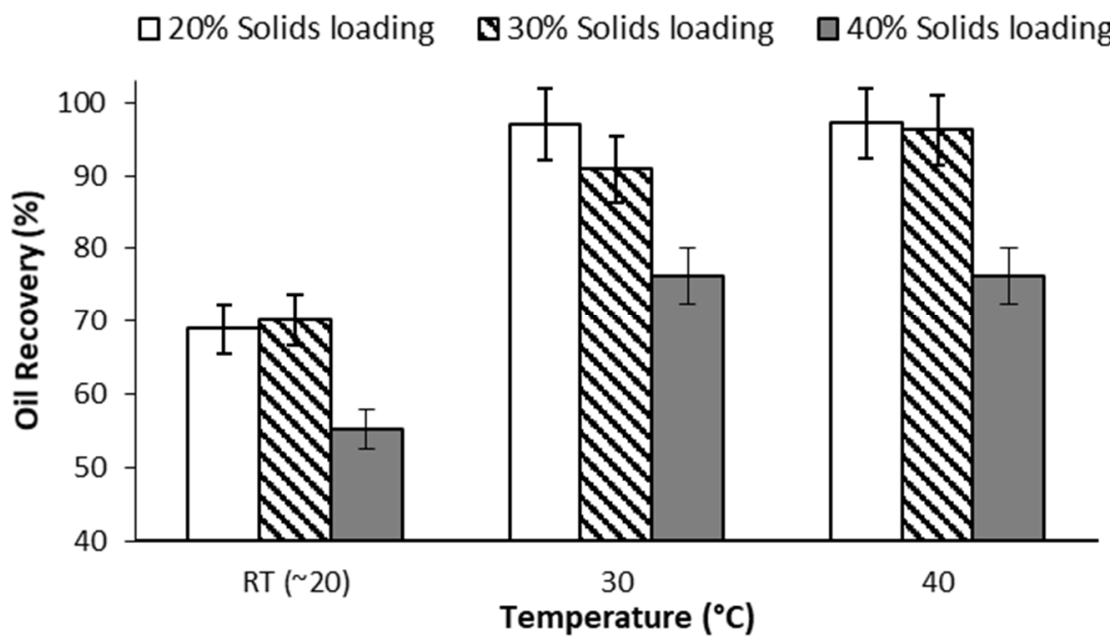

Figure 3. Effects of temperature on oil recovery from heavy fraction (\# 20 sieved and aspirated) DDGS at $20 \%, 30 \%$, and $40 \%$ solids loadings.

Based on the findings, it was interpreted that the particle size of DDGS could also influence oil recovery. Fractionation of DDGS provided fractions of a particular particle size that could expand the interface between the substance particles and the aqueous solvent or enzyme [24] and thus improve the free oil yield. Several particle size reduction methods were developed, such as grinding and sieving [30], colloid milling [13], dry milling [24], elutriation process [31], etc. These methods were used for efficient oil recovery from various corn ethanol coproducts. However, some of these methods were complex, energy-intensive, and difficult to replicate. Therefore, we used a simple sieving and aspiration technique to separate DDGS into particular sizes for higher oil recovery.

Figure 3 also shows that when the temperature changed from room temperature to $30{ }^{\circ} \mathrm{C}$, oil recovery increased significantly for $40 \%$ solids loading. Following the similar trend for $20 \%$ and $30 \%$ solids loading, increasing the temperature above $30{ }^{\circ} \mathrm{C}$ did not affect the oil recovery for $40 \%$ solids loading. Only $76 \%$ of the oil was recovered both at $30{ }^{\circ} \mathrm{C}$ and $40{ }^{\circ} \mathrm{C}$. Even though it would be much more efficient for the industry to use higher solids loadings for more oil recovery, the ethanol industry would not be interested in high energy input for less than $80 \%$ oil recovery. Considering these aspects, a temperature of $30{ }^{\circ} \mathrm{C}$ with $30 \%$ solids loadings would be sufficient for maximum oil recovery from the heavy fraction (\# 20 sieved and aspirated) DDGS.

\subsection{Oil Partitioning in Whole Stillage by Using Ethanol}

Four different forms of oil may be found in whole stillage: oil inside unbroken cells of germs and endosperm, oil droplets connected with hydrophobic particle surfaces, oil-inwater emulsion and oil in unbroken oil bodies (oleosomes) [32]. Luangthongkam et al. [9] assumed that after centrifuging the whole stillage oil inside unbroken cells and attached to larger debris could partition into solid fraction and oil-in-water emulsion and oil in oleosomes could partition into liquid fraction. However, some emulsified oil could not 
partition into thin stillage without a demulsifier. A demulsifier, like aqueous ethanol, may dissolve soluble cellular materials and partition more oil in the liquid phase. This process of demulsification inside the whole stillage can be affected by process temperature and solids loading. In this experiment, 190 proof ethanol was used to treat whole stillage in different temperatures and solids loadings to have better oil partition in the liquid fraction.

\subsubsection{Composition of Whole Stillage Sample Used}

The composition of the whole stillage used in the experiment is listed in Table 2. A high moisture level (around 90\%) is one of the distinguishing characteristics of whole stillage. The amount of protein and oil accounted for about $48 \%$ of the whole stillage sample composition.

Table 2. Composition of whole stillage used in the experiment.

\begin{tabular}{cc}
\hline Composition (\%) & Whole Stillage $^{*}$ \\
\hline Oil & $17.45 \pm 0.02$ \\
Moisture & $30.70 \pm 0.52$ \\
Crude protein & $88.54 \pm 0.69$ \\
\hline
\end{tabular}

${ }^{*}$ Mean of triple measurements \pm standard deviation.

\subsubsection{Effects of Temperature on Oil Partitioning}

Two different temperature conditions were selected to investigate the effect of temperature on the partitioning of oil from the whole stillage. One is the room temperature $\left(\mathrm{RT} \sim 20^{\circ} \mathrm{C}\right.$ ), the other is $50{ }^{\circ} \mathrm{C}$. Table 3 displays the impact of temperature on wet yield (\% wt.), percent solids, and oil partitioning in solid and liquid fractions as a percent of whole stillage. The oil partition had a positive impact on increasing temperature. When the whole stillage was mixed with ethanol and the operating temperature was $50{ }^{\circ} \mathrm{C}$, the oil partition in the liquid fraction increased by $19 \%$ (from $19.99 \%$ in RT to $24.71 \%$ in $50{ }^{\circ} \mathrm{C}$ ). A similar trend also follows (oil partition increased from $11.59 \%$ in RT to $16.94 \%$ in $50{ }^{\circ} \mathrm{C}$ ) when whole stillage is treated with water for the same solids content as ethanol treatment. However, no significant change was found in oil partition in liquid fraction control treatments treated with different temperatures and different solids content than other treatments (Table 3). Thus, it seems that the ethanol addition may have ruptured the oil trapped emulsion. An experiment conducted by Yao et al. [8] revealed that removing ethanol from whole stillage resulted in lower oil recovery from a liquid fraction (thin stillage) with heating treatment.

Table 3. Yield and partition of oil in liquid and solid fractions corresponding to whole stillage.

\begin{tabular}{|c|c|c|c|c|c|}
\hline \multicolumn{2}{|c|}{ Treatments } & \multicolumn{4}{|c|}{ Liquid Fraction } \\
\hline Temperature & Medium (\% solids) & Wet yield $(\%)$ * & Solids content $(\%) *$ & Dry matter yield $(\%) *$ & Oil partitioning $(\%) *$ \\
\hline \multirow{3}{*}{$\begin{array}{l}\text { Room temperature } \\
\quad\left(\mathrm{RT} \sim 20^{\circ} \mathrm{C}\right)\end{array}$} & With ethanol (7.5 \%) & $75.00 \pm 2.06 \mathrm{a}$ & $2.58 \pm 0.04_{c}$ & $30.69 \pm 1.69 \mathrm{a}$ & $19.99 \pm 0.86_{b}$ \\
\hline & With water $(7.5 \%)$ & $70.34 \pm 0.05_{b}$ & $2.67 \pm 0.04_{c}$ & $28.47 \pm 0.51_{b}$ & $11.59 \pm 1.41_{c}$ \\
\hline & Control (11.5 \%) & $68.78 \pm 0.54_{b}$ & $4.69 \pm 0.27 \mathrm{a}$ & $32.81 \pm 1.04 \mathrm{a}$ & $16.86 \pm 1.75_{b}$ \\
\hline \multirow{3}{*}{$50{ }^{\circ} \mathrm{C}$} & With ethanol (7.5 \%) & $76.20 \pm 1.32 \mathrm{a}$ & $3.42 \pm 0.29 \mathrm{~b}$ & $29.67 \pm 1.14_{\mathrm{ab}}$ & $24.71 \pm 2.88 \mathrm{a}$ \\
\hline & With water $(7.5 \%)$ & $70.37 \pm 0.56_{b}$ & $2.15 \pm 0.14_{c}$ & $28.83 \pm 0.20_{\mathrm{b}}$ & $16.94 \pm 1.54_{\mathrm{b}}$ \\
\hline & Control $(11.5 \%)$ & $67.82 \pm 0.55_{b}$ & $4.57 \pm 0.16 \mathrm{a}$ & $30.42 \pm 1.69 \mathrm{a}$ & $16.99 \pm 2.20_{\mathrm{b}}$ \\
\hline \multicolumn{2}{|c|}{ LSD (Least Significant Difference) } & 2.53 & 0.52 & 2.88 & 4.21 \\
\hline & & \multicolumn{4}{|c|}{ Solid Fraction } \\
\hline \multirow{3}{*}{$\begin{array}{l}\text { Room temperature } \\
\quad\left(\mathrm{RT} \sim 20^{\circ} \mathrm{C}\right)\end{array}$} & With ethanol (7.5 \%) & $25.00_{c}$ & $22.44 \pm 1.77_{b}$ & $69.31_{\mathrm{ab}}$ & $80.01_{b}$ \\
\hline & With water $(7.5 \%)$ & $29.66_{b}$ & $19.18 \pm 0.07_{\mathrm{c}}$ & $71.53 \mathrm{a}$ & $88.41_{\mathrm{a}}$ \\
\hline & Control (11.5 \%) & $31.22 \mathrm{ab}$ & $26.60 \pm 0.21 \mathrm{a}$ & $67.19_{b}$ & $83.14_{b}$ \\
\hline \multirow{3}{*}{$50{ }^{\circ} \mathrm{C}$} & With ethanol (7.5\%) & $23.80_{c}$ & $20.58 \pm 0.03 \mathrm{bc}$ & $70.33 \mathrm{a}$ & $75.29_{c}$ \\
\hline & With water $(7.5 \%)$ & $29.63 \mathrm{~b}$ & $20.27 \pm 0.69_{c}$ & $71.17 \mathrm{a}$ & $83.06 \mathrm{~b}$ \\
\hline & Control $(11.5 \%)$ & $32.18 \mathrm{a}$ & $26.22 \pm 0.03 \mathrm{a}$ & $69.58 \mathrm{ab}$ & $83.01_{b}$ \\
\hline \multicolumn{2}{|c|}{ LSD (Least Significant Difference) } & 2.53 & 2.10 & 2.88 & 4.21 \\
\hline
\end{tabular}

* Within each column, means that are followed by different letters differ significantly $(p<0.05)$. 
Increasing temperature with ethanol addition increased the percent solids content of the liquid fraction significantly, resulting in higher oil partitioning (Table 3). In addition, the increased temperature may evaporate some moisture and result in more oil in the liquid fraction. Some previous studies already found strong correlation between oil in liquid fraction and percent solids, thus supporting our findings [7].

The wet yield of the liquid fraction ranged from $67.82-76.20 \%$ and the ethanol treatment at $50{ }^{\circ} \mathrm{C}$ resulted the highest wet yield (Table 3). These values are close to the industrial yield of liquid fraction (approximately 81\%) [4]. However, the effect of temperature with ethanol addition is not significant both on the wet yield and dry matter yield of liquid fraction.

\subsubsection{Effects of Solids Loading on Oil Partitioning}

Mixing ethanol with whole stillage results in lower solids loading than the control treatment. Water was added with whole stillage to examine the effect of the same solids loading as ethanol treatment. The control treatment percent solid was 11.5, whereas the other ethanol or water treatment percent solid was 7.5. Table 3 illustrates the effect of solids loadings on wet yield (\% wt.), solid, and oil partitioning in solid and liquid fractions as a percent of whole stillage. It is evident from Table 3 that oil partition was higher in the liquid fraction from ethanol treatments compared to other treatments, regardless of the temperature effect. After comparing the same solids loading of $7.5 \%$, the ethanol addition improved oil partition significantly (ranges from 45-72\% increase). Moreover, oil partition increased significantly with ethanol addition at a high temperature $\left(50{ }^{\circ} \mathrm{C}\right)$ relative to the control treatment (higher solids loading than others). However, ethanol addition did not significantly change oil partition at room temperature with different solids loadings than the control treatment.

The liquid fraction dry matter contents in the control and other treatments ranged from $2.15-4.69 \%$ (Table 3), which is very low relative to typical industrial values of 7.0-7.5\% [4]. It was due to the decanting process of the whole stillage. It was challenging to simulate the industrial decanting in a laboratory setting. However, the findings still give us an insight into how ethanol affected the oil partition in the whole stillage. Control treatments had higher solids to start with and significantly higher solids in the liquid fraction than other treatments. There is no significant difference found in other treatments solids content, except for the ethanol treatment at a high temperature $\left(50{ }^{\circ} \mathrm{C}\right)$. The ethanol treatment at higher temperatures resulted in significantly higher solids content relative to other treatments. The same trend is also observed in the solid fraction, which explains the increase of percent solids in the liquid fraction.

The impact of ethanol addition with lower solids increases the wet yield of liquid fraction significantly compared to other treatments (Table 3). The greater yield of a liquid fraction means energy saving in the subsequent drying phases of the DDGS, which would be a desirable outcome for the biorefinery industry. Table 3 shows that the solid partitioned in liquid fraction (dry matter yield) ranged from $28.47 \%$ to $32.81 \%$. The dry matter yield is highest in the control sample, which is reasonable because they had a higher amount of solids than others. However, lowering the solids content of whole stillage by ethanol mixing did not significantly reduce the dry matter yield compared to the control.

Wang et al. [7] reported that the dry matter yield and oil partition in liquid fraction were only generally correlated. They observed that the oil was more available in certain samples because the oil was not stored in the solids in the same way after various treatments. The dry matter yield and oil partitioning in the industrial thin stillage (liquid fraction) were reported to be 48 percent, and 53 percent, respectively [7], and those were greater than our findings. This was attributed to the difficulty of reproducing the industrial process within a laboratory environment. Wang et al. [4] stated a need for accurate simulation device/methods to produce liquid fraction and solid fraction on a bench scale from the whole stillage, as is the scenario in the dry-grind ethanol industry. 


\section{Conclusions}

The impact of ethanol on oil recovery from DDGS and oil partition from whole stillage was investigated. Ethanol was added with two different fractions of DDGS to find the effect of different solids loadings and temperatures on oil yield. Higher oil was yielded from the heavy fraction (\# 20 sieved and aspirated) of DDGS than the original. The highest oil recovery ranged from $92-95 \%$ at $30{ }^{\circ} \mathrm{C}$ with $30 \%$ solids loading from the heavy fractionated sample of DDGS. However, the oil recovery was found to be non-significant for solids loadings of $20 \%$ and $30 \%$ when the temperature was increased above $30{ }^{\circ} \mathrm{C}$. Therefore, the solids loading can be increased up to $30 \%$ without compromising the oil yield and considering the economic benefit and handling advantage. Oil recovery from DDGS increased with temperature increment, but it was not satisfactory at $40 \%$ solids loading. The whole stillage was experimented with ethanol by varying two different temperatures and solids loadings. When ethanol was used with whole stillage at high temperature $\left(50{ }^{\circ} \mathrm{C}\right), 45-72 \%$ more oil was partitioned into liquid fractions than control treatments. The outcome of this experiment showed a positive effect of ethanol addition at certain levels and increased temperature during the process on the oil partitioning of whole stillage. More research is required to scale this study from laboratory to pilot scale. Different concentrations and amounts of ethanol can be employed to achieve the best possible oil recovery for future works.

Author Contributions: Conceptualization, M.S.H. and N.N.; Methodology, M.S.H. and N.N.; Software, M.S.H.; Validation, M.S.H. and N.N.; Formal analysis, M.S.H. and N.N.; Resources, N.N.; Data curation, M.S.H. and N.N.; Writing — original draft preparation, M.S.H.; Writing—review and editing, N.N.; Visualization, M.S.H. and N.N.; Supervision, N.N.; Project administration, N.N.; Funding acquisition, N.N. All authors have read and agreed to the published version of the manuscript.

Funding: This work was partially supported by the USDA National Institute of Food and Agriculture Hatch project ND01476.

Data Availability Statement: The raw data presented in this study are available upon request.

Acknowledgments: The authors acknowledge Blue Flint Ethanol, LLC for providing the DDGS sample and Hankinson Renewable Energy, LLC for providing ethanol and whole stillage sample. Special appreciation goes out to Ewumbua Monono, Sagar Regmi, and Max Salzer for their assistance in conducting the experiments. The authors also would like to acknowledge Andrew Taylor and Jennifer Longo of the North Dakota State University Center for Writers for their writing consultation to prepare the manuscript.

Conflicts of Interest: The authors declare no conflict of interest. There is no involvement of the funders in this study's design, data collection, analysis, or interpretation, article preparation, or decision to publish the results.

\section{References}

1. Renewable Fuels Association. Essential Energy. Ethanol Industry Outlook. 2021. Available online: https://ethanolrfa.org/file/27 4/RFA_Outlook_2021_fin_low.pdf (accessed on 19 August 2021).

2. Yang, L.; Rosentrater, K.A. Physical and chemical properties of whole stillage, thin stillage and syrup. In Proceedings of the 2015 ASABE Annual International Meeting, New Orleans, LA, USA, 26-29 July 2015; p. 1.

3. Nježić, Z.; Banković-llić, I.; Stamenković, O.; Veljković, V. Environmental aspects of the production and use of corn oil biodiesel. Saf. Eng. 2018, 8, 73-78. [CrossRef]

4. Wang, H.; Wang, T.; Pometto, A.L.; Johnson, L.A. A Laboratory decanting procedure to simulate whole stillage separation in dry-grind corn ethanol process. J. Am. Oil Chem. Soc. 2009, 86, 1241-1250. [CrossRef]

5. Reis, C.E.R.; Rajendran, A.; Hu, B. New technologies in value addition to the thin stillage from corn-to-ethanol process. Rev. Environ. Sci. Bio/Technol. 2017, 16, 175-206. [CrossRef]

6. Noureddini, H.; Bandlamudi, S.R.P.; Guthrie, E.A. A Novel method for the production of biodiesel from the whole stillageextracted corn oil. J. Am. Oil Chem. Soc. 2008, 86, 83-91. [CrossRef]

7. Wang, H.; Wang, T.; Johnson, L.A.; Pometto, I.A.L. Effect of the corn breaking method on oil distribution between stillage phases of dry-grind corn ethanol production. J. Agric. Food Chem. 2008, 56, 9975-9980. [CrossRef]

8. Yao, L.; Luangthongkam, P.; Wang, T.; Lamsal, B.; Fei, T.; Wang, H.; Johnson, L.A.; Dasari, M. Improved corn ethanol fermentation and oil distribution by using polysaccharide hydrolyzing enzymes. J. Bioprocess Eng. Biorefinery 2014, 3, 323-331. [CrossRef] 
9. Luangthongkam, P.; Fang, L.; Noomhorm, A.; Lamsal, B. Addition of cellulolytic enzymes and phytase for improving ethanol fermentation performance and oil recovery in corn dry grind process. Ind. Crop. Prod. 2015, 77, 803-808. [CrossRef]

10. Thiex, N.J.; Anderson, S.; Gildemeister, B.; Adcock, W.; Boedigheimer, J.; Bogren, E.; Coffin, R.; Conway, K.; DeBaker, A.; Frankenius, E.; et al. Crude fat, hexanes extraction, in feed, cereal grain, and forage (randall/soxtec/submersion method): Collaborative study. J. AOAC Int. 2003, 86, 899-908. [CrossRef]

11. Toda, T.A.; Sawada, M.M.; Rodrigues, C.E. Kinetics of soybean oil extraction using ethanol as solvent: Experimental data and modeling. Food Bioprod. Process. 2016, 98, 1-10. [CrossRef]

12. Dickey, L.C.; Kurantz, M.J.; Johnston, D.B.; McAloon, A.J.; Moreau, R.A. Grinding and cooking dry-fractionated corn germ to optimize aqueous enzymatic oil extraction. Ind. Crop. Prod. 2010, 32, 36-40. [CrossRef]

13. Dickey, L.C.; Kurantz, M.J.; Parris, N. Oil separation from wet-milled corn germ dispersions by aqueous oil extraction and aqueous enzymatic oil extraction. Ind. Crops Prod. 2008, 27, 303-307. [CrossRef]

14. Karlovic, D.J.; Bocevska, M.; Jakovlevic, J.; Turkulov, J. Corn germ oil extraction by a new enzymatic process. Acta Aliment. 1994, 23, 389-400.

15. Moreau, R.A.; Dickey, L.C.; Johnston, D.B.; Hicks, K.B. A process for the aqueous enzymatic extraction of corn oil from dry milled corn germ and enzymatic wet milled corn germ (E-Germ). J. Am. Oil Chem. Soc. 2009, 86, 469-474. [CrossRef]

16. Rebolleda, S.; Rubio, N.; Beltrán, S.; Sanz, M.T.; González-SanJosé, M.L. Supercritical fluid extraction of corn germ oil: Study of the influence of process parameters on the extraction yield and oil quality. J. Supercrit. Fluids 2012, 72, 270-277. [CrossRef]

17. Shi, Y.; Ma, Y.; Zhang, R.; Ma, H.; Liu, B. Preparation and characterization of foxtail millet bran oil using subcritical propane and supercritical carbon dioxide extraction. J. Food Sci. Technol. 2014, 52, 3099-3104. [CrossRef]

18. Farrell, H.; Pessen, H.; Brown, E.; Kumosinski, T. Structural insights into the bovine casein micelle: Small angle X-ray scattering studies and correlations with spectroscopy. J. Dairy Sci. 1990, 73, 3592-3601. [CrossRef]

19. Campbell, K.A.; Glatz, C.E.; Johnson, L.A.; Jung, S.; de Moura, J.M.N.; Kapchie, V.; Murphy, P. Advances in aqueous extraction processing of soybeans. J. Am. Oil Chem. Soc. 2011, 88, 449-465. [CrossRef]

20. Chi, Y.; Zhang, W.; Yang, R.; Hua, X.; Zhao, W. Destabilization of stubborn emulsion formed during aqueous extraction improving extraction rate of total free oil from peanut. Trans. Chin. Soc. Agric. Eng. 2014, 30, 257-264. [CrossRef]

21. Huda, S.; Nahar, N.; Monono, E.; Regmi, S. Oil recovery from fractionated dried distillers grains with solubles (DDGS) using enzymes. Processes 2021, 9, 1507. [CrossRef]

22. Horwitz, W.; Latimer, G. (Eds.) AOAC Official Methods of Analysis of AOAC International; AOAC International: Gaithersburg, MD, USA, 2010.

23. AOCS. AOCS Official Procedure Am 5-04. Rapid Determination of Oil/Fat Utilizing High Temperature Solvent Extraction; American Oil Chemists Society: Urbana, IL, USA, 2005.

24. Ni, S.; Zhao, W.; Zhang, Y.; Gasmalla, M.A.A.; Yang, R. Efficient and eco-friendly extraction of corn germ oil using aqueous ethanol solution assisted by steam explosion. J. Food Sci. Technol. 2016, 53, 2108-2116. [CrossRef]

25. Johnson, L.A. Theoretical, comparative and historical analyses of alternative technologies for oilseeds extraction. In Technology and Solvents for Extracting Oilseeds and Nonpetroleum Oils; Wan, P.J., Wakelyn, P.J., Eds.; AOCS Press: Champaign, IL, USA, 1997; pp. 5-47. ISBN 978-0-935315-81-0.

26. Chabrand, R.M.; Kim, H.; Zhang, C.; Glatz, C.E.; Jung, S. Destabilization of the emulsion formed during aqueous extraction of soybean Oil. J. Am. Oil Chem. Soc. 2008, 85, 383-390. [CrossRef]

27. Singh, N.; Cheryan, M. Extraction of oil from corn distillers dried grains with solubles. Trans. ASAE 1998, 41, 1775-1777. [CrossRef]

28. Kadioglu, S.I.; Phan, T.T.; Sabatini, D.A. Surfactant-based oil extraction of corn germ. J. Am. Oil Chem. Soc. 2010, 88, 863-869. [CrossRef]

29. Miñana-Perez, M.; Graciaa, A.; Lachaise, J.; Salager, J.-L. Solubilization of polar oils with extended surfactants. Colloids Surfaces A Physicochem. Eng. Asp. 1995, 100, 217-224. [CrossRef]

30. Liu, K. Selected factors affecting crude oil analysis of distillers dried grains with solubles (DDGS) as compared with milled corn. Cereal Chem. J. 2010, 87, 243-249. [CrossRef]

31. Srinivasan, R.; Moreau, R.A.; Rausch, K.D.; Belyea, R.L.; Tumbleson, M.E.; Singh, V. Separation of fiber from distillers dried grains with solubles (DDGS) using sieving and elutriation. Cereal Chem. J. 2005, 82, 528-533. [CrossRef]

32. Majoni, S.; Wang, T.; Johnson, L.A. Enzyme treatments to enhance oil recovery from condensed corn distillers solubles. J. Am. Oil Chem. Soc. 2011, 88, 523-532. [CrossRef] 